\title{
Instruments to assess quality of life in patients with heart failure
}

\author{
Instrumentos de avaliação da qualidade de vida \\ em pacientes com insuficiência cardíaca
}

\section{Amanda Braga de Louredo, Ana Luiza Coelho Leite, Gisela Rosa Franco Salerno, Marcelo Fernandes, Silvana Blascovi-Assis*}

Universidade Presbiteriana Mackenzie (Mackenzie), São Paulo, SP, Brazil

\begin{abstract}
Introduction: Heart failure (HF) is a complex clinical syndrome representing the common final pathway of various heart diseases. It is characterized by low exercise tolerance, low survival rates and deteriorated quality of life. Several studies mention Quality of Life (QoL) as an important source of information on how disease truly affects patient's lives. In this context, the assessment of QoL is extremely important to provide data that support the choice of a therapeutic strategy and the assessment of the effectiveness of a treatment. Objectives: This study aimed to investigate and identify the most appropriate and widely used instrument for the assessment of quality of life in patients with HF. Methods: We searched the databases of Lilacs, Medline, Pubmed, Scielo and CAPES to identify relevant articles published in English and Portuguese between 2000 and 2010. Results: We found 25 papers that described, quoted or used instruments for the assessment of QoL in patients with HF. Conclusion: The MLHFQ is the most widely used instrument to assess QoL in patients with HF. Its good metric properties have been confirmed in a large number of studies. In
\end{abstract}

* ABL: grad, e-mail: amanda_louredo@hotmail.com ALCL: analuizacleite@hotmail.com GRFS: MCs, e-mail: gisela.franco@mackenzie.br MF: PhD, e-mail: marcelo.fernandes@mackenzie.br SBA: PhD, e-mail: silvanablascovi@mackenzie.br 
addition, it has a simple structure and is easy to administer, which makes it the most recommended instrument for this purpose.

Keywords: Questionnaires. Quality of Life. Heart failure.

\section{Resumo}

Introdução: A insuficiência cardíaca é uma complexa síndrome clínica, via final comum de várias cardiopatias, podendo ser caracterizada por baixa tolerância ao exercício, baixa sobrevida e qualidade de vida deteriorada. A Qualidade de vida (QV) vem sendo mencionada em diversos estudos como uma importante fonte de informação sobre como a doença realmente afeta a vida dos indivíduos doentes. Nesse contexto, a avaliação da QV é de fundamental importância para fornecer dados que auxiliem na decisão de uma estratégia terapêutica e na avaliação da eficácia de um tratamento realizado. Objetivos: Os objetivos desse estudo foram identificar e determinar o instrumento mais utilizado e adequado na avaliação da qualidade de vida em pacientes com IC. Metodologia: Foi feito levantamento bibliográfico, nos idiomas inglês e português, nas bases de dados Lilacs, Medline, Pubmed, Scielo, CAPES, no período entre 2000 e 2010. Resultados: Foram encontrados 25 trabalhos que descreviam, citavam ou utilizavam os instrumentos de avaliação da QV em pacientes com IC. Conclusão: Dentre os instrumentos de avaliação da QV descritos para pacientes com IC, o mais utilizado é o MLHFQ, tendo em vista suas boas propriedades métricas, que foram demonstradas em um grande número de estudos, além de possuir estrutura simples e de fácil administração, portanto mais recomendável.

Palavras-chave: Questionários. Qualidade de vida. Insuficiência cardíaca.

\section{Introduction}

Heart failure (HF) is a complex clinical syndrome initiated by the inability of the heart to pump blood at a rate commensurate with the metabolic demands of the body, i.e., the heart cannot supply the body's tissues with enough blood to ensure nutrition and proper removal of waste products. HF may be caused myocyte dysfunction or loss, ventricular remodeling or by a combination of both (1). Thus, HF is the the common final pathway of all heart diseases and is characterized by increased neurohormonal activity, low exercise tolerance, low survival rates and deteriorated quality life $(2,3)$.

Quality of life (QoL) quality of life is "the individual's perception of his/her position in life, within the context of culture and value systems in which he/ she lives and in relation to his/her objectives, expectations, standards and concerns" (4), i.e., it is a discrepancy between satisfaction and dissatisfaction with certain areas of life, according to the individual's perception, and this perception is considered the best indicator of QoL (5). In conventional language, life satisfaction refers to the fulfillment of needs, expectations, desires and wishes (2).

Health-related QoL assessments are designed to focus on the patient's own experience or interpretation of how he/she is functioning in relation to illness, i.e., they define the patient's reality, his/her point of view as opposed to the reality defined by professional medical knowledge. $(6,7)$.

The objective of QoL measurements is to identify how the disease affects the QoL of patients and how patients face and cope with their situation. Thus, QoL assessment is an important source of information, in addition to diagnostic and laboratory tests, and its use in controlled clinical trials has been growing steadily over time $(8,9,10)$. Accordingly, there is an effort of the scientific community to quantify the impact of HF on patients' lives. In this context, the assessment of QoL is extremely important to provide data that support the choice of a therapeutic strategy and the assessment of the effectiveness of a treatment.

This study aimed to investigate and identify the most appropriate and widely used instrument for the assessment of quality of life in patients with HF. 


\section{Materials and methods}

The databases of Lilacs, Medline, Pubmed, Scielo and CAPES were searched for relevant articles published in English and Portuguese between 2000 and 2010, using the following key words: heart failure, quality of life and questionnaires. In addition, a general review was conducted on books and manuals that addressed QoL in patients with HF.

Articles that described, quoted or used instruments for the assessment of QoL in patients with HF were included in this study. Studies addressing instruments that did not meet the functional and symptomatic characteristics of HF were excluded.

\section{Results}

We found 25 papers that described, quoted or used instruments for the assessment of QoL in patients with HF. These are described in the Table 1.

Table 1 - Summary and description of the questionnaires found in the literature search

(to be continued)

\begin{tabular}{|c|c|}
\hline Instrument name & Description \\
\hline $\begin{array}{l}\text { Medical Outcomes Study } \\
\text { 36-Item Short-Form Health } \\
\text { Survey (SF-36) }\end{array}$ & $\begin{array}{l}\text { This instrument is composed } \\
\text { of } 36 \text { items grouped into eight } \\
\text { subscales: physical functioning } \\
\text { (PF), role physical (RP), bodily } \\
\text { pain (BP), general health (GH), } \\
\text { vitality, social functioning, role } \\
\text { emotional and mental health. The } \\
\text { SF-36 assesses negative health } \\
\text { aspects (such as diseases or ill- } \\
\text { nesses) as well as positive ones } \\
\text { (such as well-being) (11). }\end{array}$ \\
\hline Nottingham Health Profile & $\begin{array}{l}\text { This self-administered ques- } \\
\text { tionnaire consists of } 38 \text { items, } \\
\text { based on the WHO (World } \\
\text { Health Organization) classifica- } \\
\text { tion of disabilities. The items are } \\
\text { organized into six categories: } \\
\text { energy level, pain, emotional } \\
\text { reactions, sleep, social interac- } \\
\text { tion and physical abilities. Each } \\
\text { positive response corresponds } \\
\text { to a score of one (1) and each } \\
\text { negative response corresponds } \\
\text { to a score of zero (0), giving a } \\
\text { maximum score of } 38(12) \text {. }\end{array}$ \\
\hline
\end{tabular}

Table 1 - Summary and description of the questionnaires found in the literature search

(to be continued)

\begin{tabular}{|c|c|}
\hline Instrument name & Description \\
\hline Sickness Impact Profile & $\begin{array}{l}\text { This questionnaire consists of } \\
136 \text { items addressing the fol- } \\
\text { lowing areas of the patient's } \\
\text { life: walking, self-care, mobility, } \\
\text { emotional behavior, work, sleep, } \\
\text { eating, household management } \\
\text { and recreational activities (11). }\end{array}$ \\
\hline $\begin{array}{l}\text { Minnesota Living Heart } \\
\text { Failure Questionnaire } \\
\text { (MLHFQ) }\end{array}$ & $\begin{array}{l}\text { This questionnaire is composed } \\
\text { of } 21 \text { questions relating to limi- } \\
\text { tations in lifestyle associated } \\
\text { with HF. Respondents use a } \\
5 \text {-point scale that ranges from } \\
0 \text { (none) to } 5 \text { (too much), with } \\
\text { a score of } 0 \text { representing no } \\
\text { limitation and a score of } 5 \text { rep- } \\
\text { resenting maximum limitation. } \\
\text { The total score is computed by } \\
\text { adding the individual scores of } \\
\text { questions involving a physical } \\
\text { dimension highly interrelated } \\
\text { with dyspnea and fatigue; an } \\
\text { emotional dimension and other } \\
\text { questions }(2,13) \text {. }\end{array}$ \\
\hline $\begin{array}{l}\text { Kansas City } \\
\text { Cardiomyopathy } \\
\text { Questionnaires (KCCQ) }\end{array}$ & $\begin{array}{l}\text { This questionnaire consists of } \\
23 \text { items that quantify physical } \\
\text { function, HF-specific symp- } \\
\text { toms, (such as swelling, dys- } \\
\text { pnea, fatigue), QoL, social } \\
\text { impact of the disease and self- } \\
\text { efficacy (14). }\end{array}$ \\
\hline $\begin{array}{l}\text { Quality of life in Severe } \\
\text { Heart Failure Questionnaire } \\
\text { (QLQ-SHF) }\end{array}$ & $\begin{array}{l}\text { This questionnaire consists of } \\
26 \text { items quantifying the level of } \\
\text { physical activity of respondents } \\
\text { and an analogue visual scale } \\
\text { evaluating life satisfaction ac- } \\
\text { cording to social and emotional } \\
\text { aspects. The higher the score, } \\
\text { the greater the impairment of } \\
\text { QoL (15). }\end{array}$ \\
\hline $\begin{array}{l}\text { Euro Heart Failure Quality of } \\
\text { Life Questionnaire }\end{array}$ & $\begin{array}{l}\text { This instrument incorporates } \\
\text { the assessment of functional } \\
\text { status with a wide range of } \\
\text { questions related to health sta- } \\
\text { tus and QoL that are relevant to } \\
\text { HF. It consists of } 40 \text { questions } \\
\text { about: fatigue, dyspnea, edema } \\
\text { of the ankles, appetite, sleep, } \\
\text { depression, mobility and social } \\
\text { activities. Different aspects of } \\
\text { a patient's life are assessed in } \\
\text { relation to his/her perception } \\
\text { of health and overall QoL. The } \\
\text { higher the score, the better the } \\
\text { quality of life (16). }\end{array}$ \\
\hline
\end{tabular}


Table 1 - Summary and description of the questionnaires found in the literature search

(conclusion)

\begin{tabular}{ll}
\hline \multicolumn{1}{c}{ Instrument name } & \multicolumn{1}{c}{ Description } \\
\hline & This questionnaire consists of \\
20 items, divided into 3 cat- \\
egories: dyspnea, fatigue and \\
emotional function. An increase \\
Chronic Heart Failure & in score indicates better QoL. It \\
Questionnaire (CHQ) & allows the assessment of dif- \\
& ferent types of dyspnea and \\
& fatigue, as well as different de- \\
& grees of HF severity (17).
\end{tabular}

\section{Discussion}

QoL questionnaires provide a more complete assessment of the impact of disease and treatment on the daily life of patients. They must be able to identify the presence of disease and reflect the evolutionary changes resulting from treatment, either due to its beneficial effect or due to its side effects (18). The instruments studied in this paper are used for the assessment of QoL in patients with HF and either globally or specifically evaluate the most important aspects related to a person's quality of life. As there are many instruments, there are also advantages and disadvantages in their administration.

The advantage of generic instruments is that a single instrument can be use to effectively detect changes in different aspects of patients' health status and allow for comparisons across diverse conditions and interventions (19). Their disadvantage is that is that they do not measure the specific problems of a disease and may not be sensitive enough to be able to detect small but important changes, due to their generic character (20). In this review, the following generic instruments were used to assess the QoL in patients with HF: Sickness Impact Profile, Nottingham Health Profile, Medical Outcomes Study 36-Item ShortForm Health Survey.

Because of the disadvantages of generic instruments, specific QoL instruments have been created to individually and specifically assess certain aspects of QoL and disease in a given population (HF) or for a particular function. Specific instruments have the advantages of being more responsive to changes in $\mathrm{QoL}$ that occur in a given period of time and of being more sensitive in discriminating the range of impairment in QOL because of their focus on the most relevant aspects of QOL for the problem assessed. (19). In this paper, the following HF-specific instruments were found: Chronic Heart Failure Questionnaire, Euro Heart Failure Quality of Life Questionnaire, Quality of life in Severe Heart Failure Questionnaire, Kansas City Cardiomyopathy Questionnaires e Minnesota Living Heart Failure Questionnaire.

QoL instruments alone can detect important aspects of the impact of a disease on QoL. Moreover, when used alone, they have the disadvantages of not allowing comparisons between different situations, being limited in some situations and interventions, and of being restricted to areas relevant to a certain disease, population (20) or function (16).

The Minnesota Living Heart Failure Questionnaire (MLHFQ) is currently the most commonly used specific instrument for assessing health-related QoL. It was validated and translated into Brazilian Portuguese by Carvalho in 2009 (2). The widespread use of this instrument and the larger amount of data available particularly caught our attention $(21,22$, 23). Scattolin et al. (2007) state that there is an inverse relationship between health-related QoL and functional independence, as measured by the MLHFQ $(24,25)$. Although the MLHFQ is currently the most popular specific instrument to measure QoL, it should be noted that it was originally designed to be a selfassessment tool for patients and a useful measure in clinical trials or to evaluate the effects of drugs or devices, and not to be used as a full instrument to assess QoL. Therefore, it is a valuable tool for some purposes, but not for others $(15,17,26,27)$.

Another widely used instrument for the assessment of QoL in patients with HF is the Chronic Heart Failure Questionnaire (CHQ). According to Doris (2002), the CHQ is a highly acceptable instrument to measure HF-specific quality of life and social support in Chinese populations (28). The same author also states that the CHQ is a valid and reliable instrument to measure QoL in cardiac patients.

Dunderdale et al. (2005) also reports that the CHQ is complex to administer, but this questionnaire has been designed to be the most sensitive to changes in dyspnea and fatigue, and seems to be sensitive to different severities of $\operatorname{HF}(16,29)$.

Another specific instrument used to assess QoL in patients with HF is the Euro Heart Failure Quality of Life Questionnaire. Unlike the CHQ-C, this instrument, 
which incorporates the assessment of functional status, evaluates a number of issues related to health and QoL, focusing more on perceived health and overall QoL (16, 30, 31).

The Kansas City Cardiomyopathy Questionnaires (KCCQ) quantifies physical limitation and QoL, and has proven to be a valid and reliable instrument. In addition, it seems to be very sensitive in monitoring the clinical course of patients (32). It has been used in several international studies and no differences in its administration and validation were found between countries $(32,33)$. According to Leal et al. (2010), the KCCQ allows for a direct quantification (in the clinical setting) of the benefits perceived by patients in relation to the interventions to which they are subjected, which eliminates inter-observer variability. Moreover, this instrument shows excellent sensitivity to changes in clinical condition over time, which has been observed over three months in a group of patients undergoing clinical intervention for HF (14).

The Quality of life in Severe Heart Failure Questionnaire (QLQ-SHF) has been used in several clinical trials and its validity was determined by comparing the QLQ-SHF scores with comparable areas of the Sickness Impact Profile (SIP) (15). Dunderdale et al. (2005) claims that there is no evidence to suggest that the QLQ-SHF is able to distinguish between different severities HF and that, although this instrument shows a good correlation with the SIP, it needs to be further investigated and tested to be used in the assessment of patients with chronic heart failure (34). The SIP is a generic instrument and therefore shows variable results in improving QoL in intervention groups. This may be due to its lack of sensitivity to changes in QoL in patients with HF. Studies also suggest that the SIP does not discriminate adequately between varying HF severity degrees. Thus, none of the two instruments mentioned above produce accurate results for the assessment of QoL in patients with $\operatorname{HF}(33,34)$.

Another generic instrument used to assess QoL in patients with HF is the Nottingham Health Profile (NHP). This instrument measures perceived anxieties relating to serious disabling diseases (15). It has been originally developed using the public perception of health and provides a description of how people feel when they are sick. However, it has been used in a number of clinical trials in heart failure and produced variable results. This may have been due to its lack of sensitivity to symptoms experienced by patients with $\mathrm{HF}$ and to its inability to detect disease at lower stages. Thus, small improvements over time are not detected. Therefore further studies are needed on the validity and use this instrument in patients with HF (15). According to Salmela et al. (2004), the NHP presents problems regarding its clinical validity, because the scale is too easy and does not measure the entire continuum of QoL (12). Furthermore, the questionnaire discriminates little between patients, as individuals are only divided into two skill levels. This indicates that it could be more useful when administered to more debilitated individuals. In order to be administered to more functionally capable individuals, the scale should be reviewed and more difficult items should be included. Therefore, despite being simple and easy to use, it is essential that this questionnaire is used in association with a functional assessment and/or a semi-structured interview in order to make the collected information more useful clinically (12).

Last but not least, the SF-36 was another generic instrument used for the assessment of patients with HF. This assessment tool is widely used, being the most commonly used instrument to compare specific instruments with generic instruments. It is a widely used instrument in many countries and can be found in the literature in many different languages (16). Studies also indicate that this instrument has high correlation with the classification of New York Heart Association (NYHA) (35). However, it was found that the SF-36 is more sensitive to smaller degrees of QoL impairment. The SF-36 is suitable for use in heart failure trials, especially when used in conjunction with a HF-specific instrument $(15,36,37,38)$.

According Wann-Hansson (2004), who compared QoL in patients with chronic ischemia of the lower limbs as measured by the NHP and SF-36, the SF36 produces less distorted and more homogeneous results, and shows greater internal consistency, except for social functioning one year postoperatively. Nevertheless, it was more sensitive in detecting changes over time in patients with intermittent claudication (39).

According to Garin et al. (2009), the questionnaire should be selected according to the objectives of the study, because each instrument has its own characteristics. For example, in certain situations a method that also admits of self-administration may be preferable, therefore, the ideal choice would be 
between the MLHFQ and the KCCQ, whereas the MLHFQ or CHFQ would be more appropriate for use in longitudinal studies. Despite the fact that all the specific instruments have been specifically developed to assess patients with $\mathrm{HF}$, the various questionnaires have specific dimensions, which may be of particular interest in some studies (40).

With regard to the general measures, according Leal et al. (2010), although they are valid and reliable, they also show some problems regarding: a) poor sensitivity to small changes in the symptoms (NHP, SIP and SF-36); b) assessment of domains that cannot be directly translated to HF patients (such as pain assessment in the NHP); c) assessment of domains that are inconsistent with the age group analyzed (such as question about violent exercise and its employment in patients over 75 years, as assessed by the SF-36 in HF patients, due to the high incidence and prevalence of this condition in elderly patients). Regarding the specific measures, the authors report that, despite the validity and reliability of most specific questionnaires, they show some problems regarding: a) the identification of the severity of HF (as observed in the QLQ-SHF and MLHFQ); b) their complexity, which makes them difficult to administer to patients (as is the case of the CHQ); c) their suitability for assessment of QoL beyond the setting of clinical trials (as is the case of the MLHFQ) $(14,19)$.

Thus, when choosing an instrument to assess QoL in a patient with heart failure, several practical and methodological considerations must be made. The instruments should be used for a specific purpose, be validated in individual patients or in a population of patients, be understandable, reproducible, valid and sensitive to changes, as well as easy to administer in a timely manner and adapted for use by other researchers.

\section{Conclusion}

The MLHFQ is the most widely used instrument to assess QoL in patients with HF. Its good metric properties have been confirmed in a large number of studies. In addition, it has a simple structure and is easy to administer, which makes it the most recommended instrument for this purpose.

\section{References}

1. Braunwald E, Zipes DP, Libby P, Bonow RO. Tratado de doenças cardiovasculares. 7ed. São Paulo: Elsevier; 2006.

2. Carvalho VO, Guimarães GV, Carrara D, Edimar FB, Bocchi A. Validação da versão em português do Minnesota Living with Heart Failure Questionnaire. Arq Bras Cardiol. 2009;93(1):39-44

3. Caruana L, Petrie MC, McMurray JJ, MacFarlane NG. Altered diaphragm position and function in patients with chronic heart failure. Eur J Heart Fail. 2001; $3(2): 183-7$.

4. Fleck MP et al. Desenvolvimento da versão em português do instrumento de avaliação de qualidade de vida da OMS (WHOQOL-100). Rev Bras Psiquiatr. 1999;21(1).

5. Albanesi Filho FM. What is the current scenario for heart failure in Brazil?. Arq Bras Cardiol. 2005; 85(3):155-6.

6. Wilkelmann ER, Manfroi WC. Qualidade de vida em cardiologia. Rev HCPA. 2008:28(1)

7. Bocchi EA, Vilas-Boas F, Moreira MC, Barretto AC, Lage $S$, Albuquerque D. Investigators of belief study: heart failure working group of Brazilian Society of Cardiology. Levosimendan in decompensated heart failure patients: efficacy in a Brazilian cohort. Results of the BELIEF study. Arq Bras Cardiol. 2008;90(3):182-90.

8. Guyatt GH. Measurement of health-related quality of life in heart failure. J Am Coll Cardiol. 1993;22(1)85-91.

9. WHOQOL Group. The development of the World Health Organization quality of life assessment instrument (the WHOQOL). In: Orley J, Kuyken W. (eds.). Quality of life assessment: international perspectives. Heidelberg: Springer Verlag; 1994. p. 41-60.

10. Alla F, Briancon S, Guillemin F, Juilliere Y, Mertes PM, Villemot JP, et al. Self- rating of quality of life provides additional prognostic information in heart failure. Insights into the EPICAL study. Eur J Heart Fail. 2002; 4(3):337-43.

11. Soares DA, Toledo JA, Santos LF, Lima MB, Galdeano LE. Qualidade de vida de portadores de insuficiência cardíaca. Acta Paul Enferm. 2008; 21(2):243-8. 
12. Salmella LFT, et al. Adaptação do perfil de saúde de Nottingham: um instrumento simples de avaliação da qualidade de vida. Cad. Saúde Pública 2004; 20(4):905-914.

13. Rector TS, Cohn JN. Assessment of patient outcome with the Minnesota Living with Heart Failure Questionnaire: reliability and validity during a randomized, double-blind, placebo-controlled trial of pimobendan. Am Heart J. 1992;124:1017-25.

14. Leal EM, et al. Propriedades psicométricas da versão portuguesa do Kansas City Cardiomyopathy Questionnaire na miocardiopatia dilatada com insuficiência cardíaca congestiva. Rev Port Cardiol. 2010;29.

15. Dunderdale K, Thompson DR, Miles JNV, Beer SF, Furze G. Quality-of-life measurement in chronic heart failure: do we take account of the patient perspective? Euro Jour of Heart Failure. 2005;(7):572-82.

16. Cleland JGF, et al. A survey on the quality of care among patients with heart failure in Europe. Euro. Jour. of Heart Failure. 2000;(2):123-132.

17. van den Berg-Emons HJG, Balk A, Bussmann H, Stam $\mathrm{H}$. Does aerobic training lead to a more active lifestyle and improved quality of life in patients with chronic heart failure?. Euro Jour of Heart Failure. 2004;(6):95-100.

18. Nobre MR. Qualidade de vida. Arq Bras Cardiol. 1995; (4):64.

19. Wilkelmann ER, Manfroi WC. Qualidade de vida em cardiologia. Rev HCPA. 2009:28.

20. Evangelista LS, Moser DK, Westlake C, Hamilton MA, Fonarow GC, Bracup K. Impact of obesity on quality of life and depression in patients with heart failure. Euro Jour oh Heart Failure. 2006;(8):750-5.

21. van den Berg-Emons RJ, Bussmann JB, Balk AH, Stam $\mathrm{HJ}$, et al. Factors associated with the level of movement-related everyday activity and quality of life in people with chronic heart failure. Phys Ther. 2005 Dec;85(12):1340-8.

22. Saccomann ICR, Cintra FA, Gallani MC. Psychometric properties of the Minnesota Living with Heart Failure Brazilian version - in the elderly. Qual Life Res. 2007; 16:997-1005.
23. Bocchi EA, Vilas-Boas F, Perrone S, Caamaño AG, Clausell N, Moreira Mda C, et al. I Latin American guidelines for the assessment and management of decompensated heart failure. Arq Bras Cardiol. 2005; 85(supl 3):49-94;1-48.

24. Scatollin FAA, Diogo MJD, Colombo RCR. Correlação entre instrumentos de qualidade de vida relacionada à saúde e independência funcional em idosos com insuficiência cardíaca. Cad. Saúde Pública. 2007 nov;2705-11.

25. Lenne RT, Dencker K, Gordon A, Jansson E, Sylven C. Comprehensive local muscle training increases aerobic working capacity and quality of life and decreases neurohormonal activation in patients with chronic heart failure. Euro. Jour. of Heart Failure. 2001;47-52.

26. Hobbs FDR, Kenkre JE, Roalfe AK, Davis RC, Hare R, Davies MK. Impact of heart failure and left ventricular systolic dysfunction on quality of life. Euro Heart Jour. 2001;23:1867-76.

27. Lewis EF, et al. Characterization of health-related quality of life in heart failure patients with preserved versus low ejection fraction in CHARM. Euro Jour of Heart Failure. 2007;(9):83-91.

28. Yu DSF, Lee DTF, Woo J. Chronic heart failure questionnaire and the medical outcome study social support survey. HSRC Report; 2002.

29. Lee DTF, Yu D, Woo J, Thompson D. Health-related quality of life in patients with congestive heart failure. Euro Jour of Heart Failure. 2000;(7):419- 22.

30. Witte KKA, Nikitin NP, Parker A C, Haeling S, Volk DH, Anker SD, et al. The effect of micronutrient supplementation on quality-of-life and left ventricular function in elderly patients with chronic heart failure. Euro Heart Jour. 2005; 2238-44.

31. Tavares LR, Velarde LG, Miranda VA, Mesquita ET. Percepções sobre diagnóstico e manuseio da insuficiência cardíaca: comparação entre cardiologistas clínicos e médicos de família. Arq Bras de Cardiol. 2006;87(2).

32. Karavidas A, et al. Effects of functional electrical stimulation on quality of life and emotional stress in patients with chronic heart failure secondary to ischaemic or idiopathic dilated cardiomyopathy: a randomised, placebo-controlled trial. Euro Journ of Heart Failure. 2008;(10):709-13. 
33. Eurich DT, Johnson JA, Reid KJ, Spertus JA. Assessing responsiveness of generic and specific health related quality of life measures in heart failure. Heal and Qual of Life Outco. 2006;(4):89.

34. Carter WB, et al. Validation of an interval scaling: the sickness impact profile. Health Services Research. 1999.

35. Alehagen U, Rahmqvist M, Paulsson T, Levin LA. Quality-adjusted life year weights among elderly patients with heart failure. Euro Jour of Heart Failure. 2008;1033-9.

36. Pihl E, Jabobsson, Fridlund B, Strfmberg A, Mertensson J. Depression and health-related quality of life in elderly patients suffering from heart failure and their spouses: a comparative study. Euron Jour of Heart Failure. 2005;(7):583-9.

37. Omran H, Illien S, Carter DM, Cyr JS, Luderitz BL. D-Ribose improves diastolic function and quality of life in congestive heart failure patients: a prospective feasibility study. Euro Jour of Heart Failure. 2003; (5):615-9.
38. Radzewitz A, et al. Exercise and muscle strength training and their effect on quality of life in patients with chronic heart failure. Euro Jour of Heart Failure. 2002;(4):627-34.

39. Hansson CW, Hallberg IR, Risberg B, Klevsgard R. A comparison of the Nottingham Health Profile and short form 36 health survey in patients with chronic lower limb ischaemia in alongitudinal perspective. Heal and Qual of life Outcomes. 2004.

40. Garin 0, et al. Disease-specific health-related quality of life questionnaires for heart failure: a systematic review with meta-analyses. Qual Life Res. 2009; 18: 71-85.

Received: 04/25/2011 Recebido: 25/04/2011

Approved: 05/12/2014 Aprovado: 12/05/2014 